\title{
Skill of Location Analysis in Social Studies Curriculum and Textbooks of Turkey
}

\author{
Abdullah TÜRKER ${ }^{1}$ \\ Gazi University, Ankara, TURKEY
}

1PhD. Gazi University, Faculty of Gazi Education, Department of Geography Education, Ankara, TURKEY. abdullahturker82 [at] gmail.com. ORCID: 0000-0003-3839-2735

\begin{abstract}
Knowing the location of historical and geographical events and the timeframe when the facts occurred is of great importance for establishing a cause-and-effect relationship. Although it is easy to find a location with the technology developing in daily life, location analysis knowledge and skills are needed to determine the location using nature or to analyze the advantages and disadvantages of the current location. Primary and secondary school education are important for students to acquisition locational analysis skills; the foundations are laid in the pre-school period. In this study, the aim is to explain how location analysis skills are considered in the 2018 Social Studies course curriculum and textbooks. In this study, a document review method is used to examine the 2018 Social Studies course curriculum and Social Studies textbooks. As a result of document analysis with descriptive analysis management, only four textbooks contain location analysis skills, which is one of the 27 Skills included in the Social Studies course curriculum. A total of six acquisitions were found to be associated at the grade 4 level. It was determined that the book section on four of the achievements associated with the location analysis skill in the program was quite successful, and the other parts related to the two achievements were far from acquisitioning the location analysis skill. As a result of the research, it is recommended that other grade levels include achievements in location analysis skills and that textbooks be better equipped to acquisition skills.
\end{abstract}

\section{Keywords}

Geographical Skill; Location Analysis; Social Studies 
In the formal education-training process, which we can express as the process of acquisitioning aims and behaviors set within the framework of a specific plan, the basic content of each course is determined by the educational programs. Students are expected to acquire knowledge and skills under the guidance of both teachers and textbooks prepared in accordance with the determined curriculum. From 1924 until 2005, most of the instructional program in the Social Studies curriculum (SSCEC) includes acquisition of knowledge as well as skills. According to the 2005 SSCEC, skills are defined as abilities designed to for students to acquire in the learning process and to ensure their transference to daily life (Ministry of National Education (MoNE), 2005). Although skills training have been among the aims of the National Education Basic Law since 1973, the implementation in schools started with the 2005 curriculums (Artvinli, 2020). With the change in primary education programs, it is seen that instead of the approach of memorizing information, students take the approach of reaching the information themselves, learning by doing-living and using the knowledge they have learned in their lives. In order to achieve this, common and special field skills are included in the curriculum (Gelen, 2011). Artvinli (2010), on the other hand, refers to the skills included in all educational programs as skills that students must learn to use during their lives.

In the 2005 SSCEC, six field skills were included along with nine common skills at the fourth and seventh grade level. In the 2018 SSCEC, a total of 27 skills were included under the basic skills heading, removing the common and field skill expressions. Before achievements can be given according to the learning areas at each grade level, the skills that will be acquisitionby the students are also included in the processing of the relevant learning area (MoNE, 2005; MoNE, 2018). Compared to the 2005 and 2018 SSCEC in terms of geographical skills, nine geographical skill acquisitions were included in the 2005 SSCEC, while 22 acquisitions were included in the 2018 SSCEC. In addition to the skills from 2005 SSCEC, the 2018 SSCEC includes location analysis, change and continuity detection, map literacy and environmental literacy skills. This can be expressed as an indication that the importance given to Geography subjects is increasing within the scope of Social Studies course (Çiftçi \& Akça, 2019).

When the literature is examined, it will be seen that a lot of research has been done, especially about skill acquisition in the Social Studies course curriculum for students; the activities and benefits of teachers in the process of acquisitioning skills; examining the structure of skills; and comparing the skill size of 2005-2018 curriculum (Baykara, 2006; Demir, 2006; Narin \& Aybek, 2010; Çelikkaya, 2011; Gelen, 2011; Çelikkaya, 2012; Sönmez \& Aksoy, 2012; Mutluer, 2013; Sönmez \& Aksoy, 2013; Taşkıran, Baş \& Bulut, 2016; Çoban \& Akşit, 2018; Çelik \& Kamıș, 2019; Çelikkaya, Yıldırım \& Kürümlüoğlu, 2019; Çiftçi \& Akça, 2019).

There are more skills in 2018 course for Geography that are associated with the issues of social studies course curriculum between environmental literacy, observation, map literacy, using evidence, location analysis, spatial perception, tables, graphs, diagrams, time and chronology by interpreting and drawing capabilities include detection. Ünlü (2011) and Bozyiğit \& Akça (2017) define the concept of geographical skills as the abilities that are intended for attaiment by 
students in the process of teaching Geography. Geographical skills as identified in a Geography education project performed within the scope of the standard in 1994 include: 1) Ask geographical questions; 2) Gather geographical information, 3) Edit geographical information, 4) Analyze geographic information, and 5) To communicate answers to geographical questions (Huynh, 2009).

In order to acquire geographical skills, it is important to start from the primary school level and develop the necessary content and planning in accordance with the abiities of the class level. With the primary education, skills directly related to Geography should be included in the curriculum, such as environmental literacy, location knowledge, spatial perception and change and continuity perception. The knowledge and skills acquisitioned within the scope of Geography, which studies natural and human events and phenomena occurring in place and space, are necessary for a better perception of the environment and a good life.

As a result of the integration of technology into the educational process, the location analysis skill was intended for acquisition by feeding into map literacy and spatial perception skills in 2005 SSCEC. However, location analysis skills were considered to be a separate skill in 2018 SSCEC to increase secondary school students' awareness of technology and develop the acquisition of location analysis abilities (Çepni, 2019). It is necessary for each person to have the ability to know, recognize and evaluate the characteristics of their location or location and their relationship with their immediate environment for their daily life. However, most individuals do not understand spatial and location relationship analysis in a healthy way throughout their teaching life. Without this skill, it is very difficult for people to recognize the environment in which they live, to establish relations with other environments, to choose the place of establishment of a residence or production facility, and to be prepared for natural disasters. In order to solve these challenges, skills that require map and location analysis must be acquired by students during their educational life (Azzari, Zamperlina \& Landia, 2013).

Basic geographical skills, such as location analysis, mapping and navigation, are among the skills that are primarily intended for students from primary school to university education in most countries. From the first grade in the United States of America, studies are carried out to provide students with location, map and direction skills within the Social Studies course. As a result of the importance given to these skills, when you ask a citizen on the street for an address, it will be seen that they correctly use the concepts of direction (for example, west-north, rather than right-left expressions) in directions (Tuna, Demirci \& Gültekin, 2012). It can be seen that topics related to Geography are focused on five basic concepts in the teaching processes and in geographical research. Concepts that can be considered as place, location, relations between places, mobility (migration) and regions are used as tools in explaining and teaching geographical issues (Taşkıran, Baş \& Bulut, 2016).

Currently, the share of Geographic Information Systems (GIS) in acquiring the ability to location analyze in the teaching of Geography is increasing. Place and location in a way that will appeal to different senses of the Google Earth application, aerial photos, internet sites, smartphone and tablet applications, and applications of GIS, offer a detailed review of the location of equipment and are a 
great contribution to the development of locational analysis abilities (Wiegand, 1993; Çepni, 2013; Aydın, 2017).

It can be assumed that the need for location-direction and location analysis skills are decreasing today, when access and sharing of locational information is becoming easier through mobile phones and navigation systems. However, developments with technology require people to have a basic level of locational analysis skills in our ability to find directions and perform location analysis. Basic teaching activities starting with Life Science courses should be further developed with Social Studies courses in order to develop the ability to teach and analyze concepts containing locational knowledge. Location-direction together with locational knowledge and analysis skills being acquired at a young age are of great importance to people's lives. Acquiring technology-independent locational analysis skills in young people are emphasized every time technology usage levels are high; such skills can also be vital in urgent and important situations where we cannot reach technology. In this study, an examination occurs about how location analysis is evident in SSCEC as a separate skill and how it is handled in textbooks..

\section{Methodology}

In this research, document review from qualitative research methods was used. Document review is a technique based on document review and analysis, especially printed and electronic materials. Corbin \& Strauss (2008) suggest that document reviews, infer from, and creates knowledge to improve analysis and interpretation of data and empirical perspective as a method of essential references.

The study of a document analysis method covers the study of written materials related to targeted events and facts. Document analysis is a qualitative research method and is widely used in situations where observation and interview methods are not possible (Yıldırım \& Şimșek, 2018). Ekiz (2009) refers to the data provided by a document analysis method as secondary data, including the process of systematic collection, examination and evaluation of public or private documents produced by public institutions. Patton (2014) proposes that documents are valuable in that they provide information to the researcher at many points that cannot be observed, and can reveal aims and decisions that cannot be calculated by the researcher. Yıldırım \& Şimşek (2018) lists the stages of a document review method as: accessing documents, originality-checks, understanding documents, analyzing data, and using data. Such stages were taken into account in the data collection and analysis processes of this research.

\section{Data Collection}

The data of this research conducted by a document analysis method is the 2018 Social Studies course curriculum (SSCEC) and Social Studies textbooks. Ministry of National Education (MoNE) curriculum monitoring and Evaluation System accessed at http://mufredat.meb.gov.tr. All skill acquisitions in SSCEC were examined and a table was created by examining the skill acquisitions that directly related to the skill of locational analysis. A total of twenty-seven skills have been included in the SSCEC, and it is valuable to note that some skills have little place in 
the curriculum. Location analysis skill is also one of the few skills given in SSCEC when looking at the state of acquisition and direct association of subjects. Social Studies 4-5-6-7 curriculum taught in primary and secondary school institutions and the classroom textbooks that have a great impact on the implementation phase are examined. The chosen Social Studies textbooks approved by the Ministry of Education and distributed to schools for use in the classroom were accessed through the Educational Information Network (EIN). The cover images of these books are given in Figure 1.

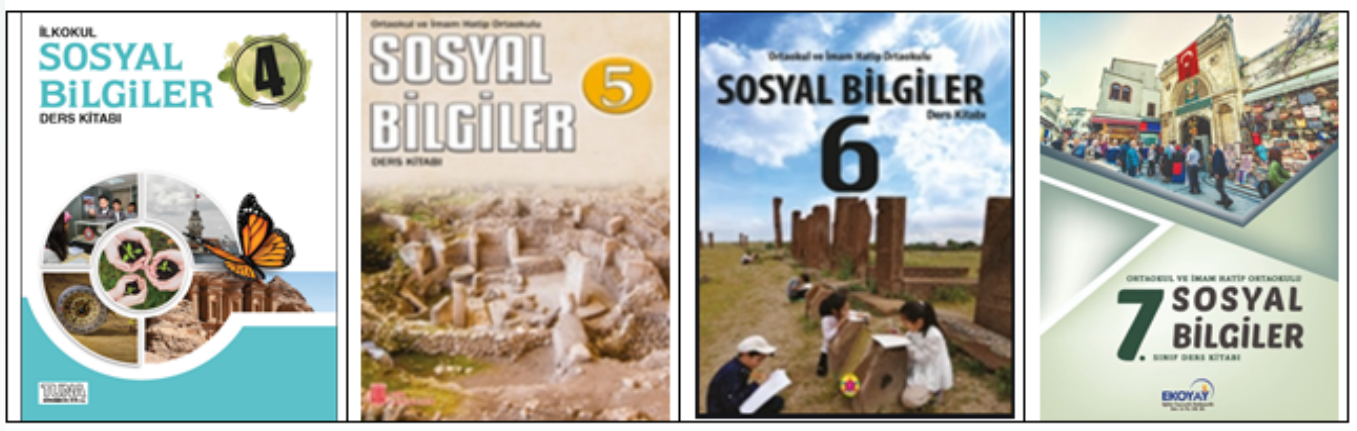

Figure 1. Social studies textbooks available from education information network

\section{Data Analysis}

The data collected within the scope of the research was analyzed using descriptive analysis method. By examining the skills and achievements in SSCEC, a table has been prepared to determine which achievements the location analysis skill is associated with. A description occurs about how the subjects relate to locational analysis skills in the relevant textbook. Expert opinion was consulted for the collected data and analysis of how the location analysis skill is given in SSCEC and textbooks. As part of the validity and reliability of qualitative research, expert opinions are of great importance. For expert opinion, interviews were conducted with three faculty members working in the field of Geography education, Social Studies education and Educational Sciences. After expert opinions, the final version of the data analysis was reported..

\section{Findings}

In this part of the research, the results obtained by examining the acquisitions and sections associated with location analysis in the textbooks related to the Social Studies course curriculum and MoNE are included. In 2018 SSCEC, the achievements associated with the locational analysis skills are one of 27 skills expected to be acquired by students in accordance with the Turkish Qualifications Framework (TQF). This information is given in Table 1. 
Türker, A. (2021). Skill of location analysis in social studies curriculum and textbooks of Turkey.

Table 1

Acquisitions Associated with Location Analysis Skills in SSCEC for Grade 4

\begin{tabular}{|c|c|c|}
\hline Grade & $\begin{array}{l}\text { Learning } \\
\text { Area }\end{array}$ & Acquisition \\
\hline 4 & $\begin{array}{l}\text { People, } \\
\text { places and } \\
\text { environments }\end{array}$ & $\begin{array}{l}\text { SS.4.3.1. It makes inferences about the location of any place } \\
\text { around it. } \\
\text { Location analysis is performed in terms of directions, proximity } \\
\text { to natural and human elements, distance. Natural and } \\
\text { technological direction finding methods and tools are addressed. } \\
\text { SS.4.3.2. It sketches the places he uses in his daily life. } \\
\text { Shelter, emergency gathering place, emergency exit and other } \\
\text { safe areas are shown on the sketch. } \\
\text { SS.4.3.3. It distinguishes the natural and human elements in the } \\
\text { environment in which it lives. } \\
\text { Students are allowed to recognize their immediate environment } \\
\text { with all its elements. } \\
\text { SS.4.3.4. By observing the weather events occurring around it, } \\
\text { he transfers findings to lllustrated graphs. } \\
\text { The observation time is determined in such a way as to allow the } \\
\text { observation of different weather events. It also focuses on the } \\
\text { ability to read and create charts when conveying weather events. } \\
\text { SS.4.3.5. It makes inferences about where he lives and the } \\
\text { landforms and population characteristics around. } \\
\text { The political and Physical Map of Turkey is examined together } \\
\text { with the students. } \\
\text { During the processing of this acquisition, literary products such } \\
\text { as poetry, stories, and epics are used. } \\
\text { SS.4.3.6. Make the necessary preparations for natural disasters. } \\
\text { Priority is given to natural disasters that are likely to occur in the } \\
\text { environment in which the student lives. Earthquake bag } \\
\text { preparation is discussed. }\end{array}$ \\
\hline
\end{tabular}

In this study, four of the acquisitions associated with location analysis capability in the 2018 SSCEC, are shown in Table 1 . The location analysis capability appear in the learning area People, Places and Environments. For 2018 SSCEC taught in Grades 4.5.6.7., there are a total of 131 achievements and 432 lesson hours reserved in the curriculum for teaching these achievements. Between this number of acquisition and course hours, only six acquisitions and 20 course hours are allocated to location analysis skills in SSCEC for Grade 4.

In this study, four textbooks distributed to schools by the MoNE and reached from the EIN are also examined. Sixty-one to 92 of the acquisition subjects associated with location analysis is in the books. "Where we live" is given as the unit heading. The lectures given in this section are discussed on the basis of achievements.

For SS.4.3.1. "It makes inferences about the location of any place around it": As for its acquisition, our aspects were entered with the question "What can be the benefits that knowing the aspects can provide us?" Karagöz-Hacivat dialogue was used to increase students' interest and motivation on the subject. After the main 
and intermediate directions are shown on a figure, then visual and descriptive information can be used to find directions (such as the location of the Sun, the Polar Star, mosses, decks, clock method, cemetery, compass, GPS) is given. Visual and descriptive information about the methods to be used in direction finding is organized in a very descriptive and instructive manner. It is believed that the level of preparation of the textbook as a visual and descriptive text will make a great contribution to providing students with the ability to analyze the location. At the end of the subject, there is an activity prepared for students to strengthen the aspects.

For SS.4.3.2. "It sketches the places uses in his daily life": The topics covered by the acquisition are given with two pages under the heading "Let's make a location description". An example of a sketch was given in the section that began with expressions aimed at understanding the bird's-eye view point and students were asked to draw a sketch showing the places known to everyone in the neighborhood where they lived. Considering the contribution that location analysis will make to the skill development of students, it has been concluded that there is a section that will offer contributions to introduce, describe or describe the places we live by using the concepts of direction taught in the previous section.

For SS.4.3.3, "It distinguishes the natural and human elements in the environment in which it lives": The issues within the scope of acquisition is given on three pages of the textbook with the title "What is there going on around us? Six photographs of natural and human elements are included. By using these photographs, definitions and examples of natural and human elements were mentioned.

After the lecture, a text was given and students were asked to write natural and human elements in the text. At the end of the chapter, the question is asked "What are the natural and human elements that you see between your school and your home?" It is believed that the assignment on the subject will be useful for students to distinguish between natural and human elements in their immediate environment. It is also believed that it will be difficult to reconcile this acquisition and that associated with the acquisition of location analysis in SSCEC with the fact that it is directly related to location information and analysis because skill acquisition and textbook learning are focused on the separation of natural and human elements. In order to contribute to students' location analysis skills, when talking about natural and human elements within the scope of acquisition, examples of differences shown by natural and human elements should also be included. For example, a sample of vegetation from two different climatic zones or a sample of rural dwellings from two different climatic zones will be shown and it is believed that the development of location analysis skills will also contribute to the development of this acquisition by asking students why they are different in the classroom. 
For "SS.4.3.4. "By observing the weather events occurring around it, transfers findings to Illustrated graphs.": The issues covered acquisition are given in a fourpage section of the textbook titled "Weather." After talking about weather events and what the weather is in the section, a weather table and graph are included based on observations made by the student. At the end of the section, which also mentioned the activities and duties of the General Directorate of Meteorology, students were asked to observe the weather in the area where their homes are located for a week and record it by measuring the temperature with a thermometer, and then create a weekly temperature chart. By examining the skill acquisition and the chapter knowledge from the textbook, it is clear that it greatly contributes to the development of the ability to "draw and interpret tables, graphs and diagrams", which is at least as important as location analysis for students. In this section, tables and graphs showing that the weather and temperature values in the centers located in different locations (such as Seaside-mountainous area or humid climate-arid climate) were used to contribute to the development of location analysis skills in students. It is believed that by asking them to compare the weather characteristics of the place they lived with another province or country they went to before in the class with another example, they will also contribute to the ability to analyze the location based on their reasons.

For SS.4.3.5. "It makes inferences about where he lives and the landforms and population characteristics around him.": The topics covered by the acquisition are given as five pages in the textbook under the heading "Where we live". As stated in the acquisition description, The Map of the Administrative Divisions of Turkey (the acquisition description in the SSCEC and the phrase political map of Turkey were used in the textbook. This title is not used by the General Directorate of maps. The title political map is used for maps showing borders drawn between countries by political treaties. For this reason, the acquisition and the use of the phrase in the textbook are incorrect.). In using the physical map of Turkey, students were asked to examine the location of their location. Based on this, examples of literary products such as folk songs, poems and epics that reflect the location characteristics of some places in our country (for exmaple, Çarşambayı sel aldı folk song and Oltu legend) were completed. As a homework assignment at the end of the subject, students were asked to conduct research on literary products describing the location characteristics of the place in which they lived. It is believed that the skill acquisition and section in the textbook will contribute greatly to the development of location analysis skills along with map skills in students.

For SS.4.3.6. "Make the necessary preparations for natural disasters.": The issues covered by its acquisition are discussed in detail under the textbook heading "Let's be prepared for natural disasters". In the section, information about the causes of the occurrence of natural disaster types and ways of protection were successfully transmitted using texts created from the mouths of students living in cities where disasters are frequent, in visual and maps. More information about 
earthquakes, which concern the entire country in natural disasters and lead to more loss of life and property, was also included using the earthquake risk map. At the end of the issue, the information given about what should be found in an earthquake emergency-bag is useful information that is vital for Turkey as a natural disaster country. As part of this topic, it is clear that students from areas where natural disasters occur will explain the causes of formation from their mouths and include an earthquake risk map with visuals, which will make an important contribution to acquiring the ability to analyze the location.

\section{Result and Discussion}

The study of 2018 SSCEC shows that the skill acquisitions associated with location analysis skills ocur only six time within the "People, Places and Environments" learning area at the fourth grade level. Among the 131 achievements in the Social Studies course that are planned to be taught for four years, a total of six achievements among the skills expected are to be acquired by students during teaching. The location analysis given only at the fourth grade level can be considered a deficiency because there are achievements at different class levels that can be directly associated with the ability to analyze location. As an example of these acquisitions, SS.6.3.1.. "Defines the geographical location of continents, oceans and our country using concepts related to location" and SS.6.3.4. "Based on human life in different natural environments of the world" makes inferences about climate characteristics. Acquisitions can be given and should not be limited to the ability to analyze location alone. It would be useful to plan all of the acquisitions in SSCEC in a balanced way, taking into account issues between classes.

In the textbooks prepared according to the 2005 SSCEC, it was envisaged to acquire one skill under a learning area or theme, while in the 2017 SSCEC it was proposed to acquire more than one skill in one learning area (Çoban \& Akşit, 2018). The program, which was first implemented in 2017 and updated with a final version from 2018, is only seen at fourth grade, "People, Places and Environments". In this area of learning, it is also desirable to acquire the skills of "detecting space, using maps, analyzing location, drawing and interpreting tables, graphs and diagrams" (MoNE, 2018a). It is thought that it would be more appropriate to give achievements that are directly related to skills, as in the 2018 Geography course curriculum, rather than collectively giving skills under the learning area in general without distinguishing them for achievements under the learning area. (MoNE, 2018b)

In a study conducted by Çelikkaya, Yıldırım \& Kürümlüoğlu (2019), teachers were asked to choose the top five skills in order of importance among the 27 skills included in SSCEC. As a result of the research, one of the skills that was never demonstrated by any Social Studies teacher in the top five was the ability to analyze the location. It can be said that the location analysis skill was among the skills used for the first time with the draft curriculum in 2017. But the fact that teachers are not among the first skills that come to mind also raises concerns that students may be further sidelined at the point of acquisition. 
"SS.4.3.1. It makes inferences about the location of any place around it.", "SS.4.3.2. It sketches the places uses in daily life.", "SS.4.3.5. It makes inferences about where it lives and the landforms and population characteristics around.", and "SS.4.3.6. Make the necessary preparations for natural disasters." are all in the chapters of the fourth grade Social Studies textbooks, prepared as a guide for teaching achievements. It was found the textbooks have content that will contribute to the acquisition of location analysis skills for students. In addition to detailed and descriptive information about the achievements, it is obvious that a great contribution will be made to acquiring the ability to analyze the location using images, maps and events. It is quite difficult to say the same thing among the achievements associated with the ability to analyze the location in SSCEC "SS.4.3.3. It distinguishes the natural and human elements in the environment in which it lives" and "SS.4.3.4. By observing the weather events occurring around it, the findings are transferred to to Illustrated graphs." in the textbook chapters. In the coded acquisition statement for SS.4.3.3 the focus is on distinguishing what natural and human elements are around us leads to a shift away from the scope of location analysis skills. In the same format SS.4.3.4. it can be stated that the coded acquisition and book section serves the ability to draw and interpret tables, charts, diagrams, and more than the ability to analyze location.

Although it is often emphasized that the achievements mentioned in educational programs are prepared to guide the teacher in teaching, skills and values for students, and the main job falls on teachers, the role of textbooks is great. Although information and resources are now easily accessible thanks to technological possibilities, there are problems at the point of accessing accurate and reliable information and not questioning its accuracy. For this reason, textbooks should be carefully prepared as the main guide and reference book. Textbooks, which are the visible face of a well-prepared curriculum, are also of great importance for the success of the program. Öztürk \& Öğreten (2017) and Aydemir (2017) in their research on the adequacy of textbooks in acqusitioning skills in 2005 SSCEC, they concluded that textbooks are not sufficient in acqusitions skills in accordance with the opinions of teachers. Similar to the studies conducted by Artvinli \& Kaya (2010) and Artvinli (2009), it would be useful to conduct studies to determine the levels of learning outcomes and skills in SSCEC in textbooks.

Although the way skills are given in the curriculum and textbooks is important, the course teacher's view and abilities to acquire skills also play a big role. It will be useful for teacher candidates to take the necessary courses related to teaching skills during their undergraduate education. It is also believed that planning inservice training activities will benefit senior teachers who are active but have not encountered skills training issues in the first years of their professional education and professional life. Contrary to what is thought, a study conducted by Gelen (2011) on the acquisition of some common thinking-related skills concluded that teachers with professional seniority of 21 years and above are more effective in acquiring thinking skills. 


\section{Suggestions}

Only the fourth grade of skill acqusitions associated with location analysis ability were examined in accordance with the results and results of the study. It is recommended that textbooks be examined at other grade levels and that textbooks are made more adequate at the point of acquiring the skills specified in the curriculum. It is also recommended for researchers to use extracurricular learning environments within the scope of Social Studies courses to help students acquire location analysis skills, as well as to conduct practical studies on this topic..

\section{References}

Artvinli, E. (2020). Coğrafi sorgulama becerisi. In Ç.Ö. Demirbaş (Ed.), Coğrafi beceriler (1st ed.). Ankara: Nobel Yayın Dağıtım.

Artvinli, E. (2012). Integrate geographic skills with active learning in geography: a case of Turkey. Journal of Research and Didactics in Geography (J-READING), 0, 1, 43-50 DOI: 10.4458/1005-06.

Artvinli, E. \& Kaya, N. (2010). Implementation level of geographic skills in 11. year geography textbook. Turkish Journal of Social Research, 14(1), 305-320. Retrieved from https://app.trdizin.gov.tr/publication/paper/detail/TVRBNE5UY3dNQT09.

Artvinli, E. (2009). The level of the access to geographic skills in the 9. year geography textbook according to the geography curriculum. Erzincan University Journal of Education Faculty, 11(2), 51-66. Retrieved from https://dergipark.org.tr /en/pub/erziefd/issue/6001/80019.

Aydemir, M. (2017). Examination of middle school social sciences text books in terms of skills included in the middle school social sciences course curriculum. Uluslararast Güncel Eğitim Araştırmaları Dergisi, 3 (2), 1-17.

Aydın, F. (2017). Coğrafya öğretiminde interaktif haritaların kullanımı. In A. Sezer (Ed.), Coğrafya öğretim teknolojileri ve mekânsal tasarımı, (259-276). Ankara: Pegem Akademi.

Azzari, M., Zamperlina, P., \& Landia, F. (2013). GIS in geography teacjhing. Journal of Research and Didactics in Geography (J-READING), 2(2), 27-42.

Baykara, N. (2006). Evaluation of social sciences instruction class in terms of thinking skills, Unpublished Master's Thesis, Afyon Kocatepe Üniversitesi, Afyonkarahisar.

Bozyiğit, R. \& Akça, D. (2017). The effect of geographical questioning skill on permanance of learning with the students' attitudes and achievements. Selçuk Üniversitesi Sosyal Bilimler Enstitüsü Dergisi. 38. 72-85.

Corbin, J., \& Strauss, A. (2008). Basics of qualitative research: Techniques and procedures for developing grounded theory (3rd ed.). Sage Publications, Inc. Retrieved from https://doi.org/10.4135/9781452230153

Çelik, A. \& Kamış, E. (2019). Evaluation of social studies curriculum in the context of learning area-skill relationship. Anadolu Kültürel Araştırmalar Dergisi, 3(3), 391410.

Çelikkaya, T. (2011). Transmission level of skills in the social studies curriculum: theacher's opinions. Kastamonu Eğitim Dergisi, 19 (3), 969-990. 
Çelikkaya, T. (2012). Activities by teachers to improve students' critical thinking skills in the social studies. The Journal of Academic Social Science Studies International Journal of Social Science, 5(5), 57-74.

Çelikkaya, T., Yıldırım, T. \& Kürümlüoğlu, M. (2019). Ability hierarchies, reasons and recommendations of students and social studies teachers regarding ability in social studies curriculum, Manas Sosyal Araştırmalar Dergisi, 8 (1). 111-132.

Çepni, O. (2013). The Use of Geographic Information Systems (GIS) in Geography Teaching. World Applied Sciences Journal, 25(12), 1684-1689.

Çepni, O. (2019). Konum analizi. Bülent Aksoy, Bülent Akbaba, Bahadır Kılcan (Ed.). Sosyal Bilgilerde Beceri Eğitimi içinde (367-387). Ankara: Pegem Akademi.

Çiftçi, B. \& Akça, D. (2019). Comparison of geographical skills and geographical acquisition fields of 2005 and 2018 social studies currǵculum. Eğitimde Yeni Yaklaşımlar Dergisi, 2 (1), 33-59.

Çoban, O. \& Akşit, İ. (2018). Comparison of 2005 and 2017 social studies curriculum in terms of learning area, acquisition, concept, value and skill. Journal of History Culture and Art Research, 7(1), 479-505.

Demir, M. K. (2006). The research of fourth and fifth grade primary school students' critical thinking levels in social studies lessons according to different variables, Gazi Eğitim Fakültesi Dergisi, 26(3). 155-169.

Ekiz, D. (2009). Bilimsel araştırma yöntemleri, Ankara: Anı.

Gelen, İ. (2011). Determination of the level of acquisition of some common skills concerning thinking in the curriculum of social studies, Ondokuz Mayıs Üniversitesi Eğitim Fakültesi Dergisi, 30(1), 83-106.

Huynh, N. (2009). The role of geospatial thinking and geographic skills in effective problem solving with GIS: $k$-16 education. Theses and Dissertations (Comprehensive). 1078. https://scholars.wlu.ca/etd/1078.

Ministiry of National Education (MoNE) (2005). İlköğretim sosyal bilgiler dersi öğretim programı ve kllavuzu (4, 5, 6 ve 7 . Sinıf). Ankara: Talim ve Terbiye Kurulu Başkanlığl.

Ministiry of National Education (MoNE) (2018a). Sosyal bilgiler dersi öğretim programı (ilkokul ve ortaokul 4, 5, 6 ve 7. sinıflar). Ankara: Talim ve Terbiye Kurulu Başkanlığı.

Ministiry of National Education (MoNE) (2018b). Coğrafya Dersi Öğretim Programı (9, 10, 11 ve 12. Sinıflar). Ankara: Talim ve Terbiye Kurulu Başkanlığı.

Mutluer, C. (2013). The views of social studies teachers about the skills contained in social studies (the example of İzmir Menemen). Turkish Studies- International Periodical For The Languages, Literature and History of Turkish or Turkic, 8 (7), 355-362.

Narin, A. \& Aybek, A. (2010). Analyzing critical thinking abilities of the social studies teachers who work at the secondary stage of primary schools. C..̈. Sosyal Bilimler Enstitüsü Dergisi, 19(1), 336-350.

Öztürk T. \& Öğreten A. (2017). Teachers' opinions about the sufficiency of social studies textbooks to gain skills of the 2005 year's social studies curriculum. Anadolu Üniversitesi Ĕ̈itim Bilimleri Enstitüsü Dergisi, 7 (2), 234-259.

Patton, M. Q. (2014). Nitel araştırma ve değerlendirme yöntemleri. (Çev. M, Bütün.- S. B, Demir), Ankara: Pegem Akademi. 
Sönmez, Ö.F. \& Aksoy, B. (2012). Determination of primary education secondary stage students' map skill levels. Turkish Studies - International Periodical For The Languages, Literature and History of Turkish or Turkic, 7(1), 1905-1924.

Sönmez, Ö.F. \& Aksoy, B. (2013). Map skills and present of republic elementary school curricula. Türkiye Sosyal Araştırmalar Dergisi, 171, 269-288.

Taşkıran, C., Baş, K. \& Bulut, B.(2016). The level of acquired social studies specific skills, Sosyal Bilimler Dergisi, 6 (11). 1-19.

Tuna, F., Demirci, A. \& Gültekin, N. (2012). What is the usage level of basic geographic knowledge and skill in the society? current situation analysis of direction, location and map skills. Milli Eğitim, 41 (195), 211-227.

Ünlü M. (2011). The level of realizing geographical skills in geography lessons. Kuram ve Uygulamada Eğitim Bilimleri, 11 (4). 2115-2172.

Wiegand, P. (1993). Children and primary geography. London: Cassell.

Yıldırım, A \& Şimşek, M. (2018). Sosyal Bilimlerde Nitel Araştırma Yöntemleri (11. Baskı). Ankara: Seçkin.

\section{Biographical Statement}

Abdullah TÜRKER is a Research Assistant PhD. at the Faculty of Gazi Education in Gazi University, where he is Geogpahy Education Department. His research interest includes Geography Education, Skills Teaching, Educational Technologies, Curriculums, Disaster Literacy and Environmental Problems and Ethics. 